\section{Chlorophyll Fluorescence and Needle Chlorophyll Concentration of Fir (Abies sp.) Seedlings in Response to $\mathrm{pH}$}

\author{
B.M. Cregg \\ Department of Horticulture, Michigan State University, East Lansing, MI \\ 48824, and Department of Forestry, Michigan State University, East Lansing, \\ MI 48824
}

\author{
M.W. Duck, C.M. Rios, and D.B. Rowe \\ Department of Horticulture, Michigan State University, East Lansing, MI 48824
}

M.R. Koelling

Department of Forestry, Michigan State University, East Lansing, MI 48824

Additional index words. conifers, chlorosis, liming, Christmas trees

\begin{abstract}
We assessed variable chlorophyll fluorescence $\left(\mathrm{F}_{\mathrm{v}} / \mathrm{F}_{\mathrm{m}}\right)$ and needle chlorophyll concentration of seedlings of Maccedonia fir (Abies borisii regis Mattfeld), subalpine fir [A. lasiocarpa (Hooker) Nuttall], Sakhalin fir [A. sachalinensis (Schmidt) Mast.], Siberian fir $[A$. sibirica (Lebed.)], and Veitch fir (A. veitchii Lindl.) grown under varying soil media $\mathbf{p H}$. Soil media $\mathbf{p H}$ was modified using liquid flowable dolomitic limestone, resulting in five $\mathrm{pH}$ levels $(3.4,4.0,5.4,6.0$, and 6.8). Increasing media $\mathrm{pH}$ significantly reduced $\mathrm{F}_{\mathrm{v}} / \mathrm{F}_{\mathrm{m}}$ and needle chlorophyll concentration in all of the species tested. The effect of $\mathrm{pH}$ on photochemistry was due to depressed nutrient uptake of $\mathrm{P}, \mathrm{Mn}, \mathrm{B}$, and $\mathrm{Cu}$. Because photosynthetic quantum yield may be related to deficiencies of several elements affected by $\mathbf{p H}, \mathrm{F}_{\mathrm{v}} / \mathrm{F}_{\mathrm{m}}$ may serve as a criterion to select for improved $\mathrm{pH}$ tolerance. Among the species examined, $A$. veitchii and $A$. lasiocarpa were most tolerant of increased pH based on $F_{v} / F_{m}$ and needle chlorophyll concentration.
\end{abstract}

Evergreen conifers are an important component of landscapes in the upper Midwest. Conifers fulfill an important design function by providing year-round color, form, and texture in landscapes as well as providing cover for wildlife. However, horticulturists are recognizing that many of the principal conifers planted in the central United States are becoming overplanted and suffer from an increasing number of pest problems. For example, Scots pine (Pinus sylvestris L.), a mainstay of landscape and Christmas tree industries, is affected by at least 40 different insects and diseases (McCullough, personal communication). Eastern white pine (Pinus strobus L.), Austrian pine (Pinus nigra Arnold), and Douglas-fir [Pseudotsugamenziesii (Mirbel) Franco] likewise are often overplanted and are hosts to a variety of pests (Dix et al., 1986; Riffle and Peterson, 1986).

True firs (Abies sp. Miller) include a number of species that may add diversity to the conifers available for landscape planting. The genus Abies includes 50 to 60 species of trees native to North and Central America, Europe, Asia, and North Africa (Farjon and Rushforth, 1989; Liu, 1971). Most species of true firs occur in cool, moist habitats in northern latitudes or at high elevation in lower latitudes. Several firs such as grand fir [Abies grandis (Douglas ex D. Don) Lindley], pacific silver fir (Abies amabilis Douglas ex J. Forbes), and noble fir (Abies procera Rehder) are large trees

Received for publication 16 Sept. 2002. Accepted for publication 5 June 2003

that are important commercial forest species in the Pacific Northwest. However, true firs have a number of characteristics that make them excellent ornamentals and Christmas trees. Firs grow straight and have a highly symmetrical growth habit. Firs also have a wide range of needle colors and lengths that can add year-round interest and variety to the landscape. While many firs are fast growers in their native environment, most are slower growing off-site.

In the upper Midwest, the use of true firs in landscapes is limited by their fairly exacting site requirements. In general, most Abies grow best on sites with good drainage, adequate moisture, and low soil pH. For example, Fraser fir [Abies fraseri (Pursh) Poiret] is native to mountainous sites with extremely acid soils; the A horizon $\mathrm{pH}$ is $\approx 3.5$, and the $\mathrm{B}$ horizon $\mathrm{pH} 3.8$ to 4.2 (Beck 1990). Concolor fir [A. concolor (Gord. \& Glen.) Hildebr.] and Canaan fir, in contrast, may grow on sites with considerably higher $\mathrm{pH}$

Table 1. Abies species studied in this trial.
(Brown, 2000; Laacke, 1990), indicating that Abies sp. vary in their $\mathrm{pH}$ tolerance. However, most information on the $\mathrm{pH}$ tolerance of firs is based on observational studies of soils in forest stands. Little direct comparative data on the relative $\mathrm{pH}$ tolerance of firs have been reported.

Increasing soil $\mathrm{pH}$ may induce chlorosis in plants due to reduced uptake of one or more nutrients, particularly phosphorus, manganese, boron, and copper (Lucas and Davis, 1961). All of these nutrients are involved, either directly or indirectly, in photosynthetic processes. Therefore, understanding the effect of increasing soil $\mathrm{pH}$ on photosynthetic function may provide an opportunity for identifying species or genotypes that are adapted to relatively alkaline conditions. The efficiency with which photosystem II captures light energy may be rapidly and nondestructively estimated as the ratio of variable to maximal chlorophyll fluorescence $\left(\mathrm{F}_{\mathrm{v}} / \mathrm{F}_{\mathrm{m}}\right)$ (Bjorkman and Demming, 1987). Because the function of the photosynthetic system is related to foliar nutrition, variable chlorophyll fluorescence may provide a rapid means to identify physiological response of plants to nutrient imbalances (Laing et al., 2000; Val et al., 1995).

The objectives of the present study were to 1) compare the response of five diverse species of true firs (Abies sp.) to varying soil $\mathrm{pH}$, and 2) determine the utility of chlorophyll fluorescence as a tool to quantify this response.

\section{Materials and Methods}

The study was conducted in a glass greenhouse at the Michigan State Univ. Plant Science greenhouse complex. We planted plug +2 or 2-2 seedlings of five Abies sp. (Table 1) in 8-L containers filled with a mixture of 3 sphagnum moss : 1 perlite (by volumev). The number of transplants per species varied from 20 to 35 , depending on availability. Seedlings were irrigated as needed with a nutrient solution of well water $\left(\mathrm{EC}=0.65 \mathrm{mS} \cdot \mathrm{cm}^{-1}\right.$ and 105,35 , and $23 \mathrm{mg} \cdot \mathrm{L}^{-1} \mathrm{Ca}, \mathrm{Mg}$, and $\mathrm{S}$, respectively) acidified with $\mathrm{H}_{2} \mathrm{SO}_{4}$ to a titratable alkalinity $130 \mathrm{mg} \cdot \mathrm{L}^{-1} \mathrm{CaSO}_{3}$ and water-soluble fertilizer providing $125 \mathrm{~N}-12 \mathrm{P}-125 \mathrm{~K}-13 \mathrm{Ca} \mathrm{mg} \cdot \mathrm{L}^{-1}$ plus $1.0 \mathrm{Fe}-0.5 \mathrm{Mn}-0.5 \mathrm{Zn}-0.5 \mathrm{Cu}-0.1 \mathrm{~B}-0.1 \mathrm{Mo}$ $\mathrm{mg} \cdot \mathrm{L}^{-1}$ (MSU Special, Greencare Fertilizers, Chicago). Greenhouse photoperiod was extended to $16 \mathrm{~h}$ using high-pressure sodium lamps. Greenhouse temperature was maintained at $20^{\circ} \mathrm{C}$.

Seedlings from each species were assigned

\begin{tabular}{|c|c|c|}
\hline $\begin{array}{l}\text { Scientific } \\
\text { name }\end{array}$ & $\begin{array}{c}\text { Common } \\
\text { names }\end{array}$ & $\begin{array}{l}\text { Geographic } \\
\text { origin }\end{array}$ \\
\hline Abies lasiocarpa (Hooker) Nuttall & Subalpine fir & W. North America \\
\hline Abies veitchii Lindl. & $\begin{array}{l}\text { Veitch fir, } \\
\text { Veitch silver fir }\end{array}$ & Japan: Honshu \\
\hline Abies sachalinensis (Schmidt) Mast. & Sakhalin fir & Russia (Sakhalin, S. Kuril Islands), Japan \\
\hline Abies sibirica Ledeb. & Siberian fir & $\begin{array}{l}\text { Russia E. from Volga River and S of } 67^{\circ} 40^{\prime} \\
\text { latitude; Turkestan; Mongolia; China }\end{array}$ \\
\hline Abies borisii regis Mattfeld & $\begin{array}{l}\text { King Boris fir, } \\
\text { Bulgarian fir, } \\
\text { Macedonian fir }\end{array}$ & $\begin{array}{l}\text { Bulgaria, N. Greece, Albania, and } \\
\text { the former Yugoslavia }\end{array}$ \\
\hline
\end{tabular}


at random to one of five $\mathrm{pH}$ treatments. Treatments were applied in a completely randomized design. Media $\mathrm{pH}$ was modified by addition of liquid flowable dolomitic limestone (28\% $\mathrm{CaCO}_{3}, 24 \% \mathrm{MgCO}_{3}$ ) (Limestone F, Cleary Chemical Corp., Dayton, N.J.) to the irrigation program. Based on a preliminary trial, four concentrations of flowable lime were applied to produce a range of soil $\mathrm{pH}$ conditions with at least $0.5 \mathrm{pH}$ difference between each level of treatment. A fifth group of seedlings did not receive dolomitic lime. Media $\mathrm{pH}$ was determined using saturated media extract weekly or bi-weekly on a subset of plants from each treatment. Flowable lime was applied as needed to maintain the seedlings at the desired $\mathrm{pH}$ level.

After 30 weeks exposure to the $\mathrm{pH}$ treatments, we measured dark-adapted variable chlorophyll fluorescence $\left(\mathrm{F}_{\mathrm{v}}\right)$ and maximum chlorophyll fluorescence $\left(\mathrm{F}_{\mathrm{m}}\right)$ on newly formed needles using a portable chlorophyll fluorescence system (Plant Efficiency Analyzer, Hansatech Instruments Ltd., Norfolk, England). For each measurement, a randomly selected needle was dark-adapted for $15 \mathrm{~min}$ using the manufacturer's plastic/foam clips. Fluorescence illumination was provided by an array of six high-intensity light-emitting diodes (LED), which were focused onto the sample surface to provide even illumination over the exposed leaf surface. Red actinic light of a peak wavelength of $650 \mathrm{~nm}$ was provided. A fluorometer actinic light level of $1200 \mu \mathrm{mol} \cdot \mathrm{m}^{-2} \cdot \mathrm{s}^{-1}$ was determined sufficient to saturate PSII, according to our preliminary tests per the manufacturer's instructions (Hansatech Instruments, 1997). An algorithm was used to determine the line of best fit through the initial 8-24 data points at the onset of illumination. This line of best fit was then extrapolated from time zero to determine $F_{0}$ (initial or minimal fluorescence), and $\mathrm{F}_{\mathrm{m}}$ (maximum fluorescence) was obtained at the same light intensity when the primary electron acceptor from PSII (QA) became fully reduced. Variable fluorescence $\left(F_{v}\right)$ was calculated by subtracting $F_{0}$ from $\mathrm{F}_{\mathrm{m}}$, and $\mathrm{F}_{\mathrm{v}} / \mathrm{F}_{\mathrm{m}}$ was calculated from the Plant Efficiency Analyzer (PEA) fluorometer (Hansatech Instruments, 1997).

After measuring $F_{v} / F_{m}$, we collected foliage from each seedling to determine chlorophyll content (Moran 1982; Moran and Porath, 1980). Ten 1.3-cm needle segments from each seedling were placed in glass vials with $5 \mathrm{~mL}$ $N$ - $N^{\prime}$-dimethylformaldehyde. Samples were incubated for $24 \mathrm{~h}$ at $5{ }^{\circ} \mathrm{C}$ and absorbance was read on a UV-Vis spectrophotometer (Model U-3110, Hitachi Ltd, Japan). Chlorophyll content was expressed on a leaf area basis. Total surface area of the needle segments was estimated as cross-sectional perimeter $\times 1.3 \mathrm{~cm}$ $\times 10$ needles. Needle cross-section perimeter was measured on digital photomicrographs using image analysis software (SigmaScan Pro, SPSS Inc., Chicago). Cross-sectional perimeter varied significantly by species but not $\mathrm{pH}$ treatment (data not shown).

Statistical analyses. The effect of dolomitic lime treatment on soil media $\mathrm{pH}$ was determined by repeated measures analysis of

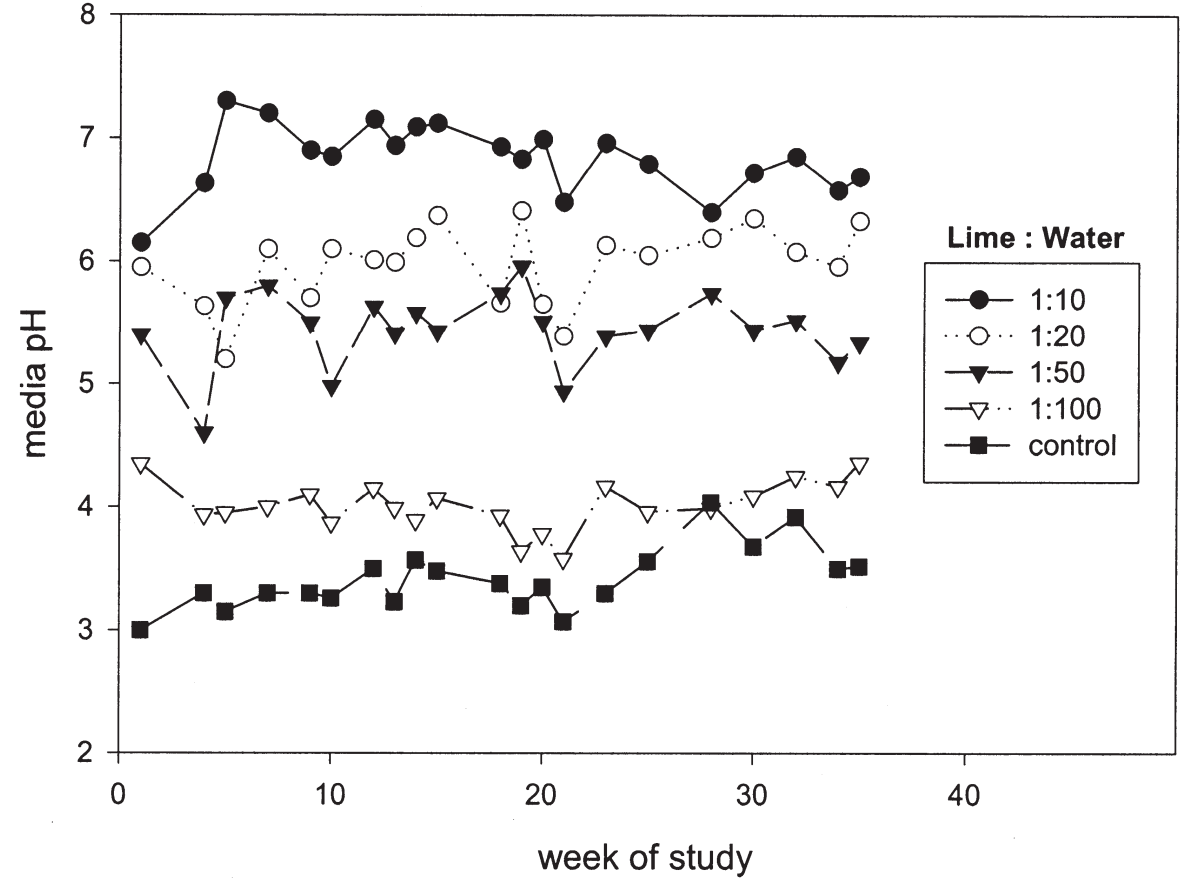

Fig. 1. Soil media $\mathrm{pH}$ of fir seedlings treated with various ratios of flowable liquid lime (Limestone FTM) and water.

variance based on 26 periodic measurements during the study. Species and $\mathrm{pH}$ treatment effects on $\mathrm{F}_{\mathrm{v}} / \mathrm{F}_{\mathrm{m}}$ and needle chlorophyll concentration were determined by analysis of variance using a fixed effects model:

$$
\mathrm{y}_{\mathrm{ijk}}=\mu+\alpha_{\mathrm{i}}+\gamma_{\mathrm{j}}+\alpha \gamma_{\mathrm{ij}}+\varepsilon_{\mathrm{ijk}}
$$

where $\mathrm{y}_{\mathrm{ijk}}=$ response of the seedling $k$; $\alpha_{\mathrm{i}}$ is the effect of species $i ; \gamma_{\mathrm{j}}$ is the effect of $\mathrm{pH}$ level $j$; and $\varepsilon_{\mathrm{ijk}}$ is the error term. Foliar nutrition samples were pooled within species and $\mathrm{pH}$ treatment to insure adequate plant material for analysis. Main effects (species and $\mathrm{pH}$ treatment) were tested for foliar nutrition using the same model as above without species $\times \mathrm{pH}$ interaction.

In order to develop a dose-response to $\mathrm{pH}$, we modeled the response of $\mathrm{F}_{\mathrm{v}} / \mathrm{F}_{\mathrm{m}}$ and chlorophyll content to varying $\mathrm{pH}$ using a linear model:

$$
\mathrm{y}=\mathrm{b}_{0}+\mathrm{b}_{1} \mathrm{x}_{\mathrm{i}}
$$

where $b_{1}$ and $b_{0}$ are coefficients; $y=F_{v} / F_{m}$ or $1 \mathrm{n}$ (chlorophyll concentration); and $\mathrm{x}=\mathrm{e}^{\mathrm{(pH})}$. Differences in the model coefficients among species were compared at the 0.05 level following a Bonferroni adjustment (Neter et al., 1985). Correlations among $\mathrm{pH}, \mathrm{F}_{\mathrm{v}} / \mathrm{F}_{\mathrm{m}}$, chlorphyll concentration, and nutrient concentrations were determined by Pearson's correlation coefficients (Steel and Torrie, 1980).

\section{Results}

Flowable lime application was effective in producing a consistent range of $\mathrm{pH}$ conditions among the treatments (Fig. 1). Averaged across the study period, the dolomitic lime application maintained at least a 0.58 unit difference between each $\mathrm{pH}$ level (Table 2). The total $\mathrm{pH}$ range achieved was $\approx 3.5 \mathrm{pH}$ units (3.38-6.80).

Photosynthetic quantum efficiency, as in- dicated by variable chlorophyll fluorescence $\left(\mathrm{F}_{\mathrm{v}} / \mathrm{F}_{\mathrm{m}}\right)$, declined with increasing $\mathrm{pH}$, especially at the highest $\mathrm{pH}$ level (Fig. 2, Table 3). Analysis of covariance indicated a significant $(P=$ 0.05 ) interaction between species and $\mathrm{pH}$. At the highest $\mathrm{pH}$ level, $\mathrm{F}_{\mathrm{v}} / \mathrm{F}_{\mathrm{m}}$ of A. lasiocarpa was significantly higher than $A$. borisii regis. A Bonferroni-adjusted comparison among coefficients indicated a significant difference in $\mathrm{F}_{\mathrm{v}} / \mathrm{F}_{\mathrm{m}}$ response to $\mathrm{pH}$ between $A$. veitchii and $A$. borisii regis.

Needle chlorophyll concentration decreased significantly with increasing $\mathrm{pH}$ (Fig. 3, Table 3). This effect reflected visible chlorosis symptoms, which were evident in seedlings at 1 lime: 50 water ratio and higher $\mathrm{pH}$ treatments. Analysis of covariance indicated that the response of chlorophyll concentration to varying $\mathrm{pH}$ differed significantly among species. Chlorophyll concentration response of $A$. veitchii to increasing $\mathrm{pH}$ was the least sensitive among the species tested (Fig. 3).

Lime treatment and lime $\times$ species interaction effects on seedling height growth were nonsignificant $(P>0.1)$. However, species varied significantly in height growth (Table 3). Abies sachalinensis grew more than all the other species except $A$. sibirica.

Foliar concentration of several nutrients

Table 2. Mean $\mathrm{pH}$ of saturated media extract from 8 -L conifer containers treated with various

\begin{tabular}{|c|c|}
\hline $\begin{array}{l}\text { Liquid lime to } \\
\text { water ratio }\end{array}$ & $\begin{array}{c}\text { Mean } \mathrm{pH}^{\mathrm{z}} \\
\text { (standard error) }\end{array}$ \\
\hline Control & $3.38(0.05)$ \\
\hline $1: 100$ & $4.02(0.04)$ \\
\hline $1: 50$ & $5.38(0.07)$ \\
\hline $1: 20$ & $5.96(0.08)$ \\
\hline $1: 10$ & $6.80(0.06)$ \\
\hline
\end{tabular}
concentrations of liquid lime.

${ }^{2}$ Mean calculated from 26 periodic measurements throughout study. 


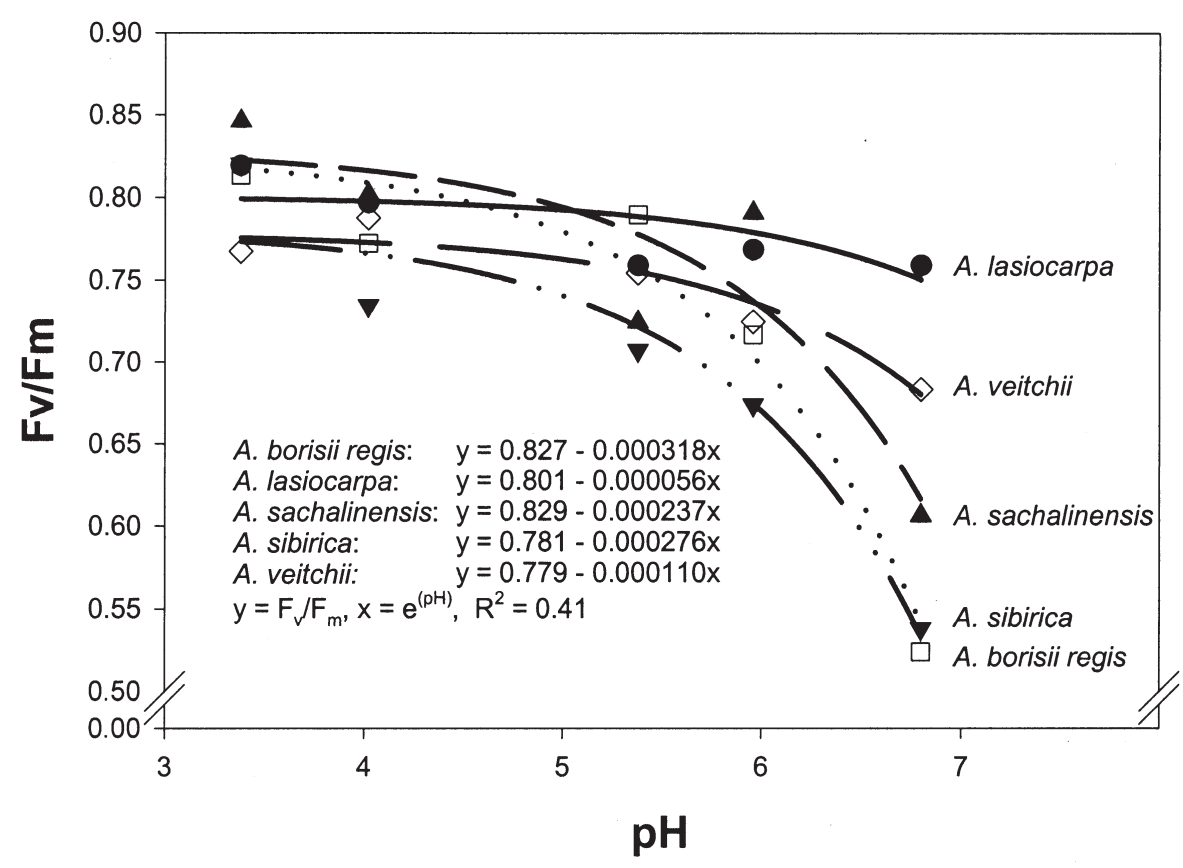

Fig. 2. Relationship between variable chlorophyll fluorescence and soil media $\mathrm{pH}$ of seedlings from five Abies species.

differed significantly among treatments and species (Table 3). Nutrient concentrations were generally lower in $A$. borisii regis relative to the other species. Foliar concentrations of $\mathrm{N}, \mathrm{P}, \mathrm{Mn}, \mathrm{B}$, and $\mathrm{Cu}$ declined in response to increasing $\mathrm{pH}$. Foliar $\mathrm{Mg}$ and $\mathrm{Ca}$ increased with $\mathrm{pH}$, due to increased availability of these ions with the dolomitic limestone treatment. Foliar Fe, S, Zn, and K were not significantly affected by lime treatment.

Chlorophyll concentration and $\mathrm{F}_{\mathrm{v}} / \mathrm{F}_{\mathrm{m}}$ were highly correlated $(r \geq 0.71, P<0.001)$. Correlation analyses suggested that photochemical response of Abies to increased $\mathrm{pH}$ is related to depression of $\mathrm{P}, \mathrm{Mn}$, and $\mathrm{Cu}$ uptake (Table 4). Correlations between $\mathrm{Ca}$ and $\mathrm{Mg}$ and other cations, such as $\mathrm{K}, \mathrm{Fe}$, and $\mathrm{Mn}$, were nonsignificant. This indicated that increased uptake of $\mathrm{Ca}$ and $\mathrm{Mg}$ from the dolomitic limestone treatment did not cause an antagonistic depression of uptake of other cations. Increased uptake of cations such as $\mathrm{K}$ and $\mathrm{Ca}$ can result in an antagonistic suppression of other cations (Sun and Payn, 1999).

\section{Discussion}

The results of this study indicate that the photochemistry of seedlings of A. lasiocarpa and $A$. veitchii is more tolerant of increasing soil alkalinity than the other species tested. Since these species have evolved in distant regions of the world, they likely have adapted to varying edaphic conditions. Abies species are know to vary widely in their response to various biotic and abiotic stresses. including resistance to fungal diseases and drought and cold tolerance (Eiga and Sakai, 1987; Guehl et al., 1991; Hinesley et al., 2000; Sakai, 1982). Although we have no specific information on the soils from which these species were selected, other Abies species occur on diverse soils and differ in $\mathrm{pH}$ tolerance. Among North American Abies species, optimum $\mathrm{pH}$ varies widely. Fraser fir and Pacific silver fir grow on strongly acid soils (pH 3.3-4.2) (Beck, 1990; Crawford and Oliver, 1990). Balsam fir grows under a wide range of soil $\mathrm{pH}$ conditions and achieves its best growth on soils with $\mathrm{pH}$ between 6.5 and 7.0 (Frank, 1990). Abies lasiocarpa, which was relatively insensitive to increasing $\mathrm{pH}$ in this study, has an extensive native range and occurs across a range of soil $\mathrm{pH}$ levels from 4.5 to 5.9 (Alexander et al., 1990).

The general decline in chlorophyll concentration and photosystem II efficiency with increasing $\mathrm{pH}$ observed here is consistent with the response reported for other firs. Bryan et al. (1989) found that seedlings of Fraser fir grew best at a soil pH between 4.2 and 4.5. Moreover, they noted that the seedlings became visibly chlorotic at soil $\mathrm{pH}$ greater than 5.0. Chlorosis of declining A. alba trees in forest stands in Switzerland was attributed to a shift in $\mathrm{pH}$ from 3.7-4.4 to 7.0-7.1 (Hiltbrunner and Flückinger, 1996).

Based on the constant-feed program in our greenhouse, all essential macro- and micronutrients were present in adequate amounts. Foliar nutrient levels in the control seedlings were in excess of published sufficiency values for related fir species (Hockman et al., 1989; Kopp and Burger, 1990; Timmer and Stone, 1978). Photosystem II efficiency of the control seedlings approached the theoretical optimum of 0.832 suggested by Bjorkman and Deming (1987).

Increasing chlorosis and reduced photosynthetic activity in firs in response to $\mathrm{pH}$ are attributed to reduced uptake of several key elements, particularly $\mathrm{Mn}, \mathrm{P}, \mathrm{B}$, and $\mathrm{Cu}$. This nutritional response closely follows the classic pattern for organic soils depicted by Lucas and Davis (1961). Their graphic representation of nutrient availability indicates that $\mathrm{B}, \mathrm{P}, \mathrm{Zn}$, and $\mathrm{Cu}$ are severely reduced as $\mathrm{pH}$ increases above 6 and that Mn availability declines sharply at $\mathrm{pH}$ higher than 5.5. All of these nutrient elements affected by $\mathrm{pH}$ are involved with photosynthetic processes and may be associated with the decreases observed

Table 3. Variable chlorophyll fluorescence, chlorophyll content, height growth, and foliar nutrition of seedlings of five Abies specie s grown in peat-perlite under varying levels of flowable dolomitic limestone.

\begin{tabular}{|c|c|c|c|c|c|c|c|c|c|c|c|c|c|c|}
\hline \multirow[b]{2}{*}{ Species $^{1}$} & \multirow[b]{2}{*}{$\mathrm{F}_{\mathrm{v}} / \mathrm{F}_{\mathrm{m}}$} & \multirow{2}{*}{$\begin{array}{c}\text { Chl a+b } \\
\left(\mathrm{mg} \cdot \mathrm{cm}^{-2}\right)\end{array}$} & \multirow{2}{*}{$\begin{array}{c}\text { Ht } \\
\text { growth } \\
(\mathrm{cm})\end{array}$} & $\mathrm{N}$ & $\mathrm{P}$ & $\mathrm{K}$ & $\mathrm{Mg}$ & $\mathrm{Ca}$ & $\mathrm{S}$ & $\mathrm{Mn}$ & $\mathrm{Fe}$ & $\mathrm{Zn}$ & $\mathrm{B}$ & $\mathrm{Cu}$ \\
\hline & & & & \multicolumn{6}{|c|}{$\left(\mathrm{g} \cdot \mathrm{kg}^{-1}\right)$} & \multicolumn{5}{|c|}{$\left(\mathrm{mg} \cdot \mathrm{kg}^{-1}\right)$} \\
\hline A. borisii regis & $0.73 \mathrm{ab}^{\mathrm{z}}$ & $0.95 \mathrm{a}$ & $1.56 \mathrm{a}$ & $28.9 \mathrm{a}$ & $2.3 \mathrm{a}$ & $19.9 \mathrm{a}$ & $1.9 \mathrm{a}$ & $3.9 \mathrm{a}$ & $2.0 \mathrm{a}$ & $224 \mathrm{a}$ & $74 \mathrm{a}$ & $43.0 \mathrm{a}$ & $18.6 \mathrm{a}$ & $5.2 \mathrm{a}$ \\
\hline A. lasiocarpa & $0.77 \mathrm{a}$ & $1.76 \mathrm{~b}$ & $0.90 \mathrm{a}$ & $32.5 \mathrm{ab}$ & $2.7 \mathrm{ab}$ & $17.7 \mathrm{a}$ & $2.2 \mathrm{ab}$ & $4.4 \mathrm{ab}$ & $2.5 \mathrm{ab}$ & $499 \mathrm{a}$ & $105 \mathrm{a}$ & $45.0 \mathrm{a}$ & $21.6 \mathrm{ab}$ & $4.8 \mathrm{a}$ \\
\hline A. sachalinensis & $0.75 \mathrm{ab}$ & $0.93 \mathrm{a}$ & $3.82 \mathrm{c}$ & $37.8 \mathrm{~b}$ & $3.0 \mathrm{~b}$ & $25.0 \mathrm{~b}$ & $2.8 b$ & $6.4 \mathrm{~b}$ & $3.0 \mathrm{~b}$ & $320 \mathrm{a}$ & $108 \mathrm{a}$ & $46.0 \mathrm{a}$ & $29.2 b c$ & $5.2 \mathrm{a}$ \\
\hline A. sibirica & $0.70 \mathrm{~b}$ & $1.16 \mathrm{a}$ & $3.14 b c$ & $36.5 \mathrm{ab}$ & $3.0 \mathrm{~b}$ & $24.4 \mathrm{~b}$ & $2.2 \mathrm{ab}$ & $5.3 \mathrm{ab}$ & $3.0 \mathrm{~b}$ & $420 \mathrm{a}$ & $104 \mathrm{a}$ & $59.8 \mathrm{a}$ & $31.4 \mathrm{c}$ & $4.8 \mathrm{a}$ \\
\hline A. veitchii & $0.74 \mathrm{ab}$ & $1.21 \mathrm{a}$ & $1.87 \mathrm{ab}$ & $34.5 \mathrm{ab}$ & $2.9 b$ & $21.3 \mathrm{ab}$ & $2.4 \mathrm{ab}$ & $4.4 \mathrm{ab}$ & $2.5 \mathrm{ab}$ & $390 \mathrm{a}$ & $88 \mathrm{a}$ & $41.2 \mathrm{a}$ & $20.4 \mathrm{ab}$ & $4.4 \mathrm{a}$ \\
\hline Treatment & & Chl $\mathrm{a}+\mathrm{b}$ & $\begin{array}{c}\mathrm{Ht}^{\mathrm{x}} \\
\text { growth }\end{array}$ & $\mathrm{N}$ & $\mathrm{P}$ & $\mathrm{K}$ & $\mathrm{Mg}$ & $\mathrm{Ca}$ & $\mathrm{S}$ & $\mathrm{Mn}$ & $\mathrm{Fe}$ & $\mathrm{Zn}$ & B & $\mathrm{Cu}$ \\
\hline (lime-water) & $\mathrm{Fv} / \mathrm{Fm}$ & $\left(\mathrm{mg} \cdot \mathrm{cm}^{-2}\right)$ & $(\mathrm{cm})$ & \multicolumn{6}{|c|}{$\left(\mathrm{g} \cdot \mathrm{kg}^{-1}\right)$} & \multicolumn{5}{|c|}{$\left(\mathrm{mg} \cdot \mathrm{kg}^{-1}\right)$} \\
\hline Control & $0.81 \times$ & $1.65 \mathrm{x}$ & $2.25 \mathrm{x}$ & $39.9 x$ & $3.1 \mathrm{xy}$ & $20.5 \mathrm{x}$ & $1.8 \mathrm{x}$ & $3.6 \mathrm{x}$ & $2.8 x$ & 449 xy & $100 x$ & $43.0 \times$ & $28.2 \mathrm{xy}$ & $5.6 \mathrm{xy}$ \\
\hline $1: 100$ & $0.77 \mathrm{xy}$ & $1.39 \mathrm{xy}$ & $2.38 \mathrm{x}$ & $40.9 x$ & $3.4 \mathrm{x}$ & $23.3 \mathrm{x}$ & $2.2 \mathrm{xy}$ & $4.1 \mathrm{x}$ & $2.9 \mathrm{x}$ & $528 x$ & $104 x$ & $50.2 x$ & $32.2 \mathrm{x}$ & $6.8 x$ \\
\hline $1: 50$ & $0.74 x y$ & $1.15 \mathrm{y}$ & $2.07 \mathrm{x}$ & $30.7 \mathrm{y}$ & $2.6 x y$ & $22.7 x$ & $2.5 x y$ & $5.2 \mathrm{xy}$ & $2.5 \mathrm{x}$ & $342 \mathrm{xy}$ & $98 \mathrm{x}$ & $51.4 \mathrm{x}$ & $21.6 \mathrm{yz}$ & $4.4 \mathrm{xy}$ \\
\hline $1: 20$ & $0.73 \mathrm{y}$ & $1.10 \mathrm{y}$ & $2.27 \mathrm{x}$ & $28.0 \mathrm{y}$ & $2.5 \mathrm{z}$ & $20.8 x$ & $2.3 \times y$ & $4.6 x$ & $2.3 \times \mathrm{y}$ & $183 \mathrm{y}$ & $89 x$ & $38.4 \mathrm{x}$ & $15.6 z$ & $4.2 x y$ \\
\hline $1: 10$ & $0.62 \mathrm{z}$ & $0.62 \mathrm{z}$ & $2.43 \mathrm{x}$ & $30.8 \mathrm{y}$ & $2.4 \mathrm{z}$ & $21.1 \mathrm{x}$ & $2.7 \mathrm{y}$ & $6.9 \mathrm{y}$ & $2.5 \mathrm{x}$ & $351 \mathrm{xy}$ & $88 x$ & $52.0 \times$ & 23.6 xyz & $3.4 \mathrm{y}$ \\
\hline
\end{tabular}

${ }^{2}$ Mean separation within each variable by Tukey's studentized range test, $P \leq 0.05$.

${ }^{\mathrm{y}}$ Species means averaged across treatments.

${ }^{x}$ Treatment means averaged across species. 


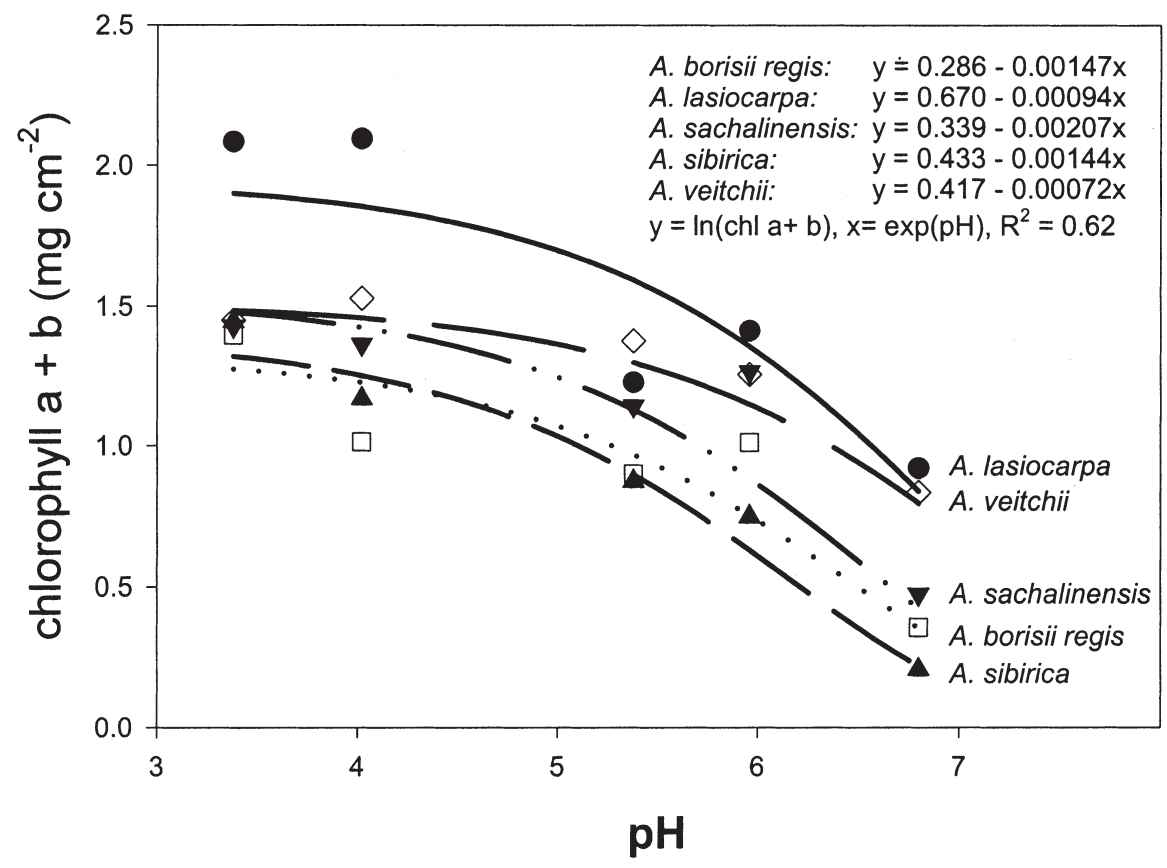

Fig. 3. Relationship between needle chlorophyll content and soil media $\mathrm{pH}$ of seedlings from five Abies species.

Table 4. Simple correlation coefficients for chlorophyll fluorescence, chlorophyll concentration, and foliar nutrients of Abies sp. seedlings under varying container media $\mathrm{pH}$.

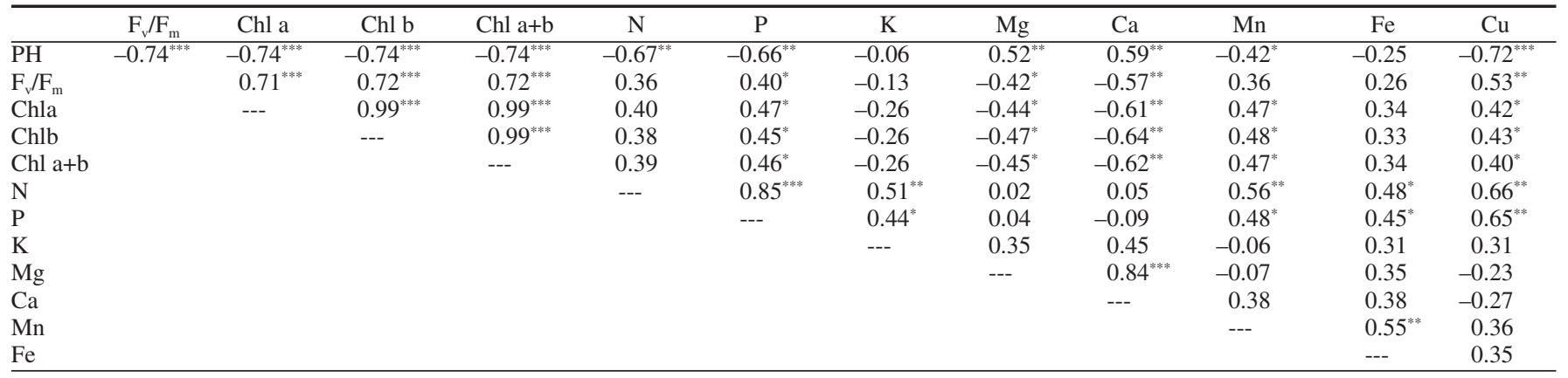

${ }^{*, * *, * * *}$ Significant at $P \leq 0.05,0.01$, or 0.0001 , respectively.

in $\mathrm{F}_{\mathrm{v}} / \mathrm{F}_{\mathrm{m}}$ and/or chlorophyll content. Variable chlorophyll fluorescence appears to provide a rapid and effective mechanism to identify $\mathrm{pH}$ tolerance among Abies species. $\mathrm{F}_{\mathrm{v}} / \mathrm{F}_{\mathrm{m}}$ was highly correlated with chlorophyll content and key elements, such as P, B, and $\mathrm{Cu}$. Val et al. (1995) found that $F_{v} / F_{m}$ was indicative of $\mathrm{Fe}$ - and Mn-induced chlorosis in pear trees. However, with respect to foliar nutrition, $\mathrm{F}_{\mathrm{v}} / \mathrm{F}_{\mathrm{m}}$ is best regarded as a general indicator of nutrient dysfunction. Relationships between chlorophyll fluorescence and nutrient deficiency have been established for P (Loustou et al., 1999), S (Kastori et al., 2000), Fe (Morales et al,. 2000), B (Kasotri et al., 1995), and Mg (Laing et al., 2000).

In summary, increasing media $\mathrm{pH}$ significantly reduced $\mathrm{F}_{\mathrm{v}} / \mathrm{F}_{\mathrm{m}}$ and needle chlorophyll concentration of the five Abies species tested. The effect of $\mathrm{pH}$ on photochemistry was due to depressed nutrient uptake of $\mathrm{P}, \mathrm{Mn}, \mathrm{B}$, and $\mathrm{Cu}$. Because photosynthetic quantum yield may be related to deficiencies of several elements affected by $\mathrm{pH}, \mathrm{F}_{\mathrm{v}} / \mathrm{F}_{\mathrm{m}}$ may serve as a criterion to select for improved $\mathrm{pH}$ tolerance. Among the species examined, A. veitchii and A. lasiocarpa were most tolerant of increased $\mathrm{pH}$ based on
$\mathrm{F}_{\mathrm{v}} / \mathrm{F}_{\mathrm{m}}$ and chlorophyll concentration. We should note however, that significant intraspecific variation has been identified in Abies for other abiotic stresses. Therefore, additional gains in $\mathrm{pH}$ tolerance may be realized from seed source testing as well as species comparisons.

\section{Literature Cited}

Alexander, R.R., R.C. Shearer, and W.D. Shepperd. 1990. Subalpine fir. In: Russell M. Burns and Barbara H. Honkala (tech. coords.). Silvics of North America: 1. Conifers. USDA For. Serv., Agr. Hdbk. 654.

Beck, D.E. 1990. Fraser fir. In: Russell M. Burns and Barbara H. Honkala (tech. coords.). Silvics of North America: 1. Conifers. USDA For. Serv., Agr. Hdbk. 654.

Bjorkman, O. and B. Demmig. 1987. Photon yield of $\mathrm{O}_{2}$ evolution and chlorophyll fluorescence characteristics at $77 \mathrm{~K}$ among vascular plants of diverse origins. Planta 170:489-504.

Brown, J.H. 2000. Survival and growth of trees of a Canaan Valley, West Virginia, seed source in relation to varying soil/site conditions. Ohio State Univ. Ext. Spec. Circ. 175-00.

Bryan, J.A., J.R. Sieler, and R.D. Wright. 1989. Influence of growth medium $\mathrm{pH}$ on growth of container-grown Fraser fir seedlings. J. Environ.
Hort. 7:62-64.

Crawford, P.D. and C.D. Oliver. 1990. Pacific silver fir. In: Russell M. Burns and Barbara H. Honkala (tech. coords.). Silvics of North America: 1. Conifers. USDA For. Serv., Agr. Hdbk. 654.

Dix, M.E., J.E. Pasek, M.O. Harrell, and F.P. Baxendale. 1986. Common insect pests of trees in the Great Plains. Great Plains Agr. Council Publ. No. 119.

Eiga, S. and A. Sakai. 1987. Regional variation in cold hardiness of Sakhalin fir (Abies sachalinensis Mast.) in Hokkaido, Japan. Plant Biol. 5:169-182.

Farjon, A. and K.D. Rushforth. 1989. A classification of Abies Miller (Pinaceae). Notes Royal Bot. Garden, Edinburgh. 46(1):59-79.

Frank, R.M. 1990. Balsam fir. In: Russell M. Burns and Barbara H. Honkala (tech. coords.). Silvics of North America: 1. Conifers. USDA For. Serv., Agr. Hdbk. 654.

Guehl, J.M., G. Aussenac, J. Bouachrine, R. Zimmerman, J. Pennes, A. Ferhi, and P. Grieu. 1991. Sensitivity of leaf gas exchange to atmospheric drought, soil drought, and water use efficiency in some Mediterranean Abies species. Can. J. For. Sci. 21:1507-1515.

Hansatech Intruments Ltd. 1997. Operating instructions for Plant Effeciency Analyzer (PEA) advanced fluorescence analysis. Hansatech 
Intruments Ltd., Norfolk, U.K.

Hiltbrunner, E. and W. Flückinger. 1996. Manganese deficiency of silver fir (Abies alba) trees at a reforested site in the Jura mountains, Switzerland: Aspects of cause and effect. Tree Physiol. 16:963-975.

Hinesley, L.E., K.C. Parker, and D.M. Benson. 2000. Evaluation of seedlings of Fraser, Momi, and Siberian fir for resistance to Phytophthora cinnimomi. HortScience 35:87-88.

Hockman, J.N., J.A. Burger, and D.W. Smith. 1989. A DRIS application to Fraser fir Christmas trees. Commun. Soil Plant. Anal. 20(3\&4):305-318.

Kastori, R., M. Plesnicar, I. Arsenijevic-Maksimovic, N. Petrovic, D. Pankovic, and Z. Sakac. 2000. Photosynthesis, chlorophyll fluorescence, and water relations in young sugar beet plants as affected by sulfur supply. J. Plant Nutr. 23(8):1037-1049.

Kastori, R., M. Plesnicar, D. Pankovic, andZ. Sakac. 1995. Photosynthesis, chlorophyll fluorescence and soluble carbohydrates in sunflower leaves as affected by boron deficiency. J. Plant Nutr. 18:1751-1763.

Kopp, V.A. and J.A. Burger. 1990. Applying diagnosis and recommendation integrated system to Fraser fir Christmas trees. Soil Sci. Soc. Amer.
J. 54:453-456.

Laacke, R.J. 1990. White fir. In: Russell M. Burns and Barbara H. Honkala (tech. coords.). Silvics of North America: 1. Conifers. USDA For. Serv., Agr. Hdbk. 654

Laing, W., D. Greer, O. Sun, P. Beets, A. Lowe, and T. Payn. 2000. Physiological impacts of $\mathrm{Mg}$ deficiency in Pinus radiata: Growth and photosynthesis. New Phytol. 146:47-57.

Liu T-S. 1971. A monograph of the genus Abies. National Taiwan Univ., Taipei.

Loustau, D., M.B. Brahim, J. Gaudillere, and E. Dreyer. 1999. Photosynthetic responses to phosphorus nutrition in two-year-old maritime pine seedlings. Tree Physiol. 19:707-715.

Lucas, R.E. and J.F. Davis. 1961. Relationships between $\mathrm{pH}$ values of organic soils and availabilities of 12 plant nutrients. Soil Sci. 92:177-182.

Morales, F., R. Belkhodja, A. Abadia, and J. Abadia 2000. Energy dissipation in the leaves of Fedeficient pear trees grown in the field. J. Plant Nutr. 23:1709-1716.

Moran., R. 1982. Formulae for determination of chlorophyllous pigments extracted with $N, N$, dimethylformamide. Plant Physiol. 69:1376-1381.

Moran, R. and D. Porath. 1980. Chlorophyll determination in intact tissues using $N, N$-demethyl- formamide. Plant Physiol. 68:478-479.

Neter, J., W. Wasserman, and M.H Kutner. 1985. Applied liner statistical models. 2nd ed. Richard D. Irwin, Inc., Homewood, Ill.

Riffle, J.W. and G.W. Peterson. 1986. Diseases of tree in the Great Plains. USDA For. Serv., Rocky Mountain For. Range Expt. Sta.

Sakai, A. 1982. Comparative study on freezing resistance of conifers with special reference to cold adaptation and its evolutive aspects. Can. J. Bot. 61:2323-2332.

Steel, R.G.D. and J.H. Torrie 1980. Principles and procedures of statistics: A biometrical approach. 2nd ed. McGraw-Hill, Kogakusha, Tokyo.

Sun, O. and T. Payn. 1999. Magnesium nutrition and photosynthesis in Pinus radiata: Clonal variation and influence of potassium. Tree Physiol. 19:535-540.

Timmer, V.R. and E.L. Stone. 1978. Comparative foliar analysis of young balsam fir fertilized with nitrogen, phosphorus, potassium and lime. Soil Sci. Soc. Amer. J. 42:125-130.

Val, J., M. Sanz, L. Montañés, and E. Monge. 1995. Application of chlorophyll fluorescence to study iron and manganese deficiency in peach tree. Acta Hort. 383:201-209. 